\title{
Rheological behavior of plant-based beverages
}

\author{
Kamilla SILVA ${ }^{1}$, André MACHADO ${ }^{2}$, Cláudio CARDOSO ${ }^{3}$, Flávio SILVA ${ }^{3 *}$ (D), Fernanda FREITAS ${ }^{4}$
}

\begin{abstract}
The aim of this research was to study the rheological behavior of a plant-based beverage made of Brazil nut (Bertholletia excelsa) and Baru (Dipteryx alata Vogel) and a nut-based beverage made of Brazil nut (Bertholletia excelsa) and Macadamia (Macadamia integrifolia) at the temperatures of 25,45 and $80^{\circ} \mathrm{C}$. Experimental data were adjusted to the models of Newton, Ostwald-de Waele, Herschel Bulkley and Bingham. The formulations of the beverages were obtained from a simplex-centroid design, based on the panelists acceptance in the sensorial evaluation. Rheological behavior showed no differences between the beverages and rheological data were best fit to Ostwald-de Waele model, at the three temperatures for both beverages, presenting a non-Newtonian behavior, with a pseudoplastic characteristic $(\mathrm{n}<1)$. In general, the nut-based beverage made of Brazil nut and Macadamia presented lower values than a plant-based beverage made of Brazil nut and Baru for an apparent viscosity, at the three temperatures, requiring less tension to flow.
\end{abstract}

Keywords: non-dairy milk; Brazil nut; Macadamia; Baru; lactose free.

Practical Applications: The data presented in this work can be applied in equipment and piping design and quality control.

\section{Introduction}

Vegetable water-soluble extracts, also known as plant-based beverages, are protein products of plant origin defined by as

[...] food obtained from protein parts of plant species, and may be presented in granules, powder, liquid or other forms, except for those that are unconventional for food, and may be added with other ingredients as long as they do not discolor the product (Brasil, 2005).

For the most part, they require the addition of hydrocolloids that act as thickening or gelling agents to improve the stability of the product (Gazola, 2014).

The stability of the product or its structure during storage is described by rheology, mainly for emulsions and other dispersions (Steffe, 1996), being one of the main problems faced by the food industry, since the destabilization of these interfaces, may alter the sensory properties and consequent compromise the acceptability of the product (Azeredo, 2012).

The knowledge of the rheological properties of food plays a fundamental role in the development of new products, in the dimensioning and operation of equipment involved in its processing, as well as in the quality control of products and processes. It also studies the influence of formulation components and relates the structure of the products with their rheological characteristics (Zheng et al., 2017).
The behavior of the fluids is described through rheological models, which relate shear stress to the shear rate of the fluid (Oliveira et al., 2008). In the literature, there are several rheological models and their choice is a function of the characteristics of the fluid. The model is considered appropriate to describe the behavior of the fluid when it provides the best adjustments of the experimental data (Silva, 2014).

Nowadays, many studies have been carried out focused on soybean water soluble extract, which was the pioneer vegetable used in the preparation of vegetable water soluble extracts, popularly known as soy milk (Ribeiro et al., 2016; Mondragón-Bernal et al., 2017; Patrignani et al., 2017; Sęczyk et al., 2017; Wang et al., 2017; Alhendi et al., 2018). Many other types of raw material can be used, such as almonds, nuts, rice, oats, among others (Sethi et al., 2016). Some studies were carried out, in laboratory scale, to obtain Brazil nut water-soluble extract (Cardarelli \& Oliveira, 2000; Ferberg et al., 2002). However, there are no reports in the literature of studies that aim to obtain the water-soluble extract of Brazil nut and Baru and water-soluble extract of Brazil nut and Macadamia.

Considering the need to understand the fluid rheology, the aim of this paper was to study the rheological behavior of the following plant-based beverages: plant-based beverage made of Brazil nut and Baru (EHCBB) and nut-based beverage made of Brazil nut and Macadamia (EHCBM).

${ }^{1}$ Departamento de Engenharia e Tecnologia de Alimentos, Instituto de Biociências, Letras e Ciências Exatas - IBILCE, Universidade Estadual Paulista Júlio de Mesquita Filho - UNESP, São José do Rio Preto, SP, Brasil

${ }^{2}$ Federal Institute Goiano - IFGoiano, Campus Rio Verde, Rio Verde, GO, Brasil

${ }^{3}$ Escola de Agronomia, Universidade Federal de Goiás - UFG, Campus Samambaia, Goiânia, GO, Brasil

${ }^{4}$ Instituto de Química, Universidade Federal de Goiás - UFG, Campus Samambaia, Goiânia, GO, Brasil

*Corresponding author: flaviocamp@gmail.com 


\section{Material and methods}

\subsection{Processing of the nut-based beverages}

In pre-tests, the best formulations of plant-based beverages were defined through a simplex-centroid design, using the acceptance of the panelists in the sensorial tests. One beverage was prepared with $69.1 \%(\mathrm{w} / \mathrm{w})$ of water, $9.2 \%(\mathrm{w} / \mathrm{w})$ of Brazil nut and $21.7 \%(\mathrm{w} / \mathrm{w})$ of Baru and for the other extract with $70.0 \%(\mathrm{w} / \mathrm{w})$ of water, $15.0 \%(\mathrm{w} / \mathrm{w})$ of Brazil nut and $15.0 \%(\mathrm{w} / \mathrm{w})$ of Macadamia. The processing of both beverages followed the methodology described by Santos (2015).

To obtain the beverages, unpeeled nuts and seeds were sanitized in $300 \mathrm{ppm}$ chlorinated water for 30 minutes and rinsed with $10 \mathrm{ppm}$ chlorinated water solution and then added in an industrial blender (LSR 25, Siemsen, Brusque, SC) water at $45{ }^{\circ} \mathrm{C}$, previously pasteurized at $80{ }^{\circ} \mathrm{C} / 25$ minutes, and the sanitized nuts mixed (in the ratio defined for each extract) and shredded for 10 minutes to obtain a product of homogeneous consistency.

The homogeneous product obtained from the mixture was centrifuged (VCC-7000, Vicini, China), resulting in two coproducts, the water-soluble extract (liquid phase) and the wet residue of the nuts and seeds (solid phase). After the centrifugation step, the water-soluble extract obtained was submitted to a heating process at $85^{\circ} \mathrm{C}$ and carboxymethylcellulose (CMC) was added with the preservatives: citric acid, potassium sorbate and sodium benzoate, all in a proportion of $0.05 \%(\mathrm{w} / \mathrm{v})$ and $10 \%(\mathrm{w} / \mathrm{v})$ crystal sugar, expressed in sucrose.

The additivation was necessary to give greater physical and physical-chemical stability to the product, increase its biological stability and improve the sensorial characteristics, especially the flavor. It should be emphasized that the additives used in the formulation of the product met the concentrations established in the legislation for coconut milk (Brasil, 2013).

Subsequently, homogenization was carried out for 5 minutes and the beverages were packed in $220 \mathrm{ml}$ glass bottles with crown cap and pasteurized at $80^{\circ} \mathrm{C}$ for 25 minutes, and finally stored under refrigeration $\left(4 \pm 2{ }^{\circ} \mathrm{C}\right)$.

\subsection{Rheological analysis}

Shear stress and apparent viscosity were obtained by a concentric cylindrical roller rheometer, model MCR 101 (Anton Parr GmbH, Ostfildern, Germany), using three continuous ramps (ascending, descending and ascending) and a shear rate ranging from 0 to $500 \mathrm{~s}^{-1}$, in order to eliminate the thixotropy.

Data from the third ascending ramp were used in the statistical analysis and experimental measurements were performed in triplicate at different temperatures, $25^{\circ} \mathrm{C}$ (ambient temperature), $45^{\circ} \mathrm{C}$ (temperature at the blending stage) and $80{ }^{\circ} \mathrm{C}$ (pasteurization temperature). The temperatures were defined in order to provide rheological data of the products aiming at a possible application on an industrial scale, based on its relevance in sizing of equipment and piping.

\subsection{Statistical analysis}

The data obtained in the rheology were adjusted using Statistica software version 7.1 (Microsoft, Tulsa, Oklahoma, United States) to the Newton, Ostwald-de Waele, Herschel- Bulkley and Bingham models, described in Equations 1, 2, 3 and 4, respectively (Table 1$)$. Coefficient of determination $\left(\mathrm{R}^{2}\right)$, relative mean error $(\mathrm{P})$ and root mean square error (RQME) were used as criterion for selecting the best models.

\section{Results and discussion}

In Table 2 are shown the rheological parameters of the beverages, as well as the respective coefficients of determination $\left(\mathrm{R}^{2}\right)$ and the errors calculated for each model at different temperatures.

After the adjustments' evaluation, all models presented high values for the determination coefficient, $\mathrm{R}^{2}>0.948$ for EHCBB and $\mathrm{R}^{2}>0.967$ for EHCBM, but this parameter alone is not enough to indicate adequately the best model (Madamba et al., 1996). Thus, analyzing errors are necessary to select the best model. If the relative mean $(\mathrm{P})$ error values are less than $10 \%$, and the more the root mean square error (RQME) approaches zero, the closer the prediction approaches of the experimental data so the model is considered appropriate to fit the data satisfactorily (McLaughlin \& Magee, 1998; McMinn, 2006; Cantu-Lozano et al., 2013).

In this sense, the Ostwald-de-Waele model, also known as Power Law, and the Herschel-Bulkley model were the ones that best fit the parameters established at all temperatures for both beverages.

Although the Herschel-Bulkley and Ostwald-de-Waele models presented a better fit than the other models, the Herschel-Buckley model showed at all temperatures evaluated in the EHCBB rheology study, negative values for the initial shear stress $\left(\tau_{0}\right)$, which is the minimum shear stress required for the fluid to start flowing (Sousa et al., 2014), which demonstrates a physical inconsistency. The same behavior was observed for the EHCBM, at temperatures of $25^{\circ} \mathrm{C}$ and $45^{\circ} \mathrm{C}$, therefore, these estimates do not match the physical meaning of the parameter. At $80^{\circ} \mathrm{C}$ for EHCBM, the same parameter was estimated in $0.059(\mathrm{~Pa})$ which is very small and may have little or no effect on a possible piping design for a product processing plant.

Therefore, Ostwald-De-Waele model provided a better adjustment to the experimental data obtained at the temperatures of $25^{\circ} \mathrm{C}, 45^{\circ} \mathrm{C}$ and $80^{\circ} \mathrm{C}$, for both plant-based beverages. These results are in agreement with those obtained

Table 1. Mathematical models for fluid flow and their equations.

\begin{tabular}{ll}
\hline \multicolumn{1}{c}{ Model } & \multicolumn{1}{c}{ Equation } \\
\hline Newton & $\tau=\mu \gamma$, \\
Ostwald-De-Waele & $\tau=K \gamma^{n}$, \\
Bingham & $\tau=\tau_{0}+\eta_{\infty} \gamma$, \\
Herschel-Bulkley & $\tau=\tau_{0}+K \gamma^{n}$,
\end{tabular}

where: $\tau=$ shear strees $(\mathrm{Pa}), \gamma=$ shear rate $\left(\mathrm{s}^{-1}\right), \mu=$ viscosity $(\mathrm{Pa} . \mathrm{s}), \mathrm{K}=$ consistency index $\left(\mathrm{Pa} . \mathrm{s}^{\mathrm{n}}\right), \mathrm{n}=$ flow behavior index (dimensionless), $\tau_{0}=$ initial shear stress $(\mathrm{Pa})$ and $\eta_{\infty}=$ plastic viscosity $\left(\right.$ Pa. $\left.s^{n}\right)$. 
Table 2. Rheological and statistical parameters of the nut-based beverages obtained for rheological models at the temperatures of $25^{\circ} \mathrm{C}$, $45^{\circ} \mathrm{C}$ and $80^{\circ} \mathrm{C}$.

\begin{tabular}{|c|c|c|c|c|c|c|c|c|c|}
\hline \multicolumn{5}{|c|}{ EHCBB } & \multicolumn{5}{|c|}{ EHCBM } \\
\hline \multirow{2}{*}{ Model } & \multirow{2}{*}{$\begin{array}{l}\text { Estimated } \\
\text { parameter }\end{array}$} & \multicolumn{3}{|c|}{ Temperature $\left({ }^{\circ} \mathrm{C}\right)$} & \multirow{2}{*}{ Model } & \multirow{2}{*}{$\begin{array}{l}\text { Estimated } \\
\text { parameter }\end{array}$} & \multicolumn{3}{|c|}{ Temperature $\left({ }^{\circ} \mathrm{C}\right)$} \\
\hline & & 25 & 45 & 80 & & & 25 & 45 & 80 \\
\hline \multirow[t]{4}{*}{ Newton } & $\mu$ (Pa.s) & 0.422 & 0.252 & 0.161 & Newton & $\mu$ (Pa.s) & 0.077 & 0.047 & 0.032 \\
\hline & $\mathrm{R}^{2}$ & 0.948 & 0.964 & 0.971 & & $\mathrm{R}^{2}$ & 0.967 & 0.983 & 0.991 \\
\hline & $\mathrm{P}(\%)$ & 20.413 & 18.454 & 17.569 & & $\mathrm{P}(\%)$ & 17.410 & 14.348 & 12.442 \\
\hline & RQME & 16.084 & 8.296 & 4.813 & & RQME & 2.454 & 1.129 & 0.578 \\
\hline \multirow{3}{*}{ Ostwald-de-Waele } & $\mathrm{R}^{2}$ & 0.999 & 0.999 & 0.999 & & $\mathrm{R}^{2}$ & 0.999 & 0.999 & 0.999 \\
\hline & $\mathrm{P}(\%)$ & 1.592 & 1.439 & 1.311 & & $\mathrm{P}(\%)$ & 3.8713 & 2.2151 & 1.586 \\
\hline & RQME & 1.040 & 0.690 & 0.247 & & RQME & 0.2939 & 0.0887 & 0.0355 \\
\hline \multirow[t]{2}{*}{ Bingham } & $\tau_{0}$ & 28.039 & 14.286 & 8.444 & Bingham & $\tau_{0}$ & 4.109 & 1.909 & 1.012 \\
\hline & & 0.338 & 0.209 & 0.136 & & & 0.065 & 0.041 & 0.029 \\
\hline \multirow[t]{6}{*}{ Herschel-Buckley } & $\tau_{0}$ & -3.656 & -1.929 & -0.137 & Herschel-Buckley & $\tau_{0}$ & -1.090 & -0.300 & 0.059 \\
\hline & $\mathrm{K}\left(\mathrm{Pa} \cdot \mathrm{s}^{\mathrm{n}}\right)$ & 3.718 & 1.720 & 0.837 & & $\mathrm{~K}\left(\mathrm{~Pa} . \mathrm{s}^{\mathrm{n}}\right)$ & 0.560 & 0.206 & 0.086 \\
\hline & $\mathrm{n}$ & 0.633 & 0.677 & 0.720 & & $\mathrm{n}$ & 0.669 & 0.752 & 0.832 \\
\hline & $\mathrm{R}^{2}$ & 0.999 & 0.999 & 0.999 & & $\mathrm{R}^{2}$ & 0.999 & 0.999 & 0.999 \\
\hline & P (\%) & 2.735 & 3.267 & 1.529 & & P (\%) & 7.290 & 4.142 & 0.973 \\
\hline & RQME & 0.814 & 0.586 & 0.246 & & RQME & 0.208 & 0.063 & 0.033 \\
\hline
\end{tabular}

where: $\tau=$ shear strees $(\mathrm{Pa}), \mu=$ viscosity $(\mathrm{Pa} . \mathrm{s}), \mathrm{K}=$ consistency index $\left(\mathrm{Pa} . \mathrm{s}^{\mathrm{n}}\right), \mathrm{n}=$ flow behavior index $($ dimensionless $), \tau_{0}=$ initial shear stress $\left(\right.$ Pa), $\mathrm{R}^{2}=$ determination coefficient,

$\mathrm{P}=$ relative mean error and $\mathrm{RQME}=$ root mean square error.

by Moreira et al. (2010) that used the Ostwald-De-Waele model to properly describe the rheological behavior of the chocolate drinks made of soybean water soluble extract and cheese whey at the studied temperatures.

A flow behavior index different of the unit $(\mathrm{n}=1)$ indicates a non-Newtonian behavior of the fluid. If $\mathrm{n}<1.0$, the fluid is defined as pseudoplastic, whereas for $\mathrm{n}>1.0$ is known as dilatant (Borges et al., 2017). The experimental results for the EHCBB showed values of flow behavior index $(\mathrm{n})$ ranging from 0.657 to 0.723 for the Ostwald-De-Waele model and ranging from 0.633 to 0.720 for the Herschel-Buckley model corroborates the pseudoplastic character of the beverage.

The values obtained from the EHCBM flow behavior index ranged from 0.710 to 0.825 for the Ostwald-De-Waele model and from 0.669 to 0.832 for the Herschel-Buckley model, confirming the pseudoplastic characteristic of the beverage. In addition, it was possible to observe the effect of the temperature on the flow behavior index which increased with the elevation of temperature, for both beverages in the used models.

Rodrigues et al. (2003) studying the rheological parameters at $25^{\circ} \mathrm{C}$ of the soybean water-soluble extract found values of $\mathrm{k}=2.08$ and $\mathrm{n}=0.69$, characterizing as non-newtonian and pseudoplastic behavior. Similar result $(\mathrm{n}=0,592)$ was observed by Lopes et al. (2019) studying UHT nut beverage at $20^{\circ} \mathrm{C}$, corroborating the results found in this study.

The consistency index $(\mathrm{K})$ is related to the degree of resistance to fluid flow (Sousa et al., 2017). It is observed, for both plant-based beverages, that it decreases as the temperature rises indicating that beverages become less consistent with the increase of temperature. This behavior was also verified by Moreira et al. (2010) in chocolate drink elaborated with soybean water-soluble extract and cheese whey. Lopes et al. (2019) studying different UHT nut beverage at $20^{\circ} \mathrm{C}$ found $\mathrm{K}=0.038$ for nut beverage, $\mathrm{K}=0.358$ for coconut beverage, $\mathrm{K}=0.047$ for hazelnut beverage and $\mathrm{K}=0.065$ for almond beverage.

Bernat et al. (2015) adjusted the flow data at $25^{\circ} \mathrm{C}$ of almond (Prunus amygdalus L. dulcis) water-soluble extract and hazelnut (Corylus avellana) water-soluble extract to the Herschel-Buckley model and found values for the consistency index $(\mathrm{K})$ of $6.2 .10^{-3}$ and 1.1.10 $10^{-3}\left(\mathrm{~Pa} . \mathrm{s}^{\mathrm{n}}\right)$, and for the flow behavior index (n) of equals to 1.18 and 1.08 , respectively. The difference between the values found by Bernat et al. (2015) with those of this study can be justified by the different raw materials used for preparing the plant-based beverages, water and nuts and seeds ratio, as well as the use of sodium carboxymethylcellulose in the formulation of the beverages.

The results show that there is a non-linear relationship between the shear rate and the shear stress (Figure 1), evidencing a typical characteristic of non-Newtonian fluid and pseudoplastic behavior (Chhabra \& Richardson, 2008).

It is observed in both beverages that at the lower temperatures correspond the higher values of viscosity, denoted by the highest position of the curves in the relationship between shear stress and strain rate. In general, the lower values for the shear stress at 


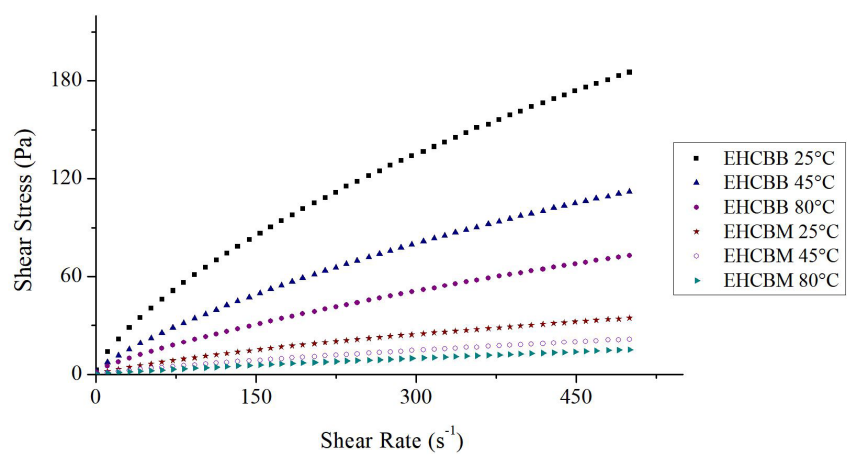

Figure 1. Reograms of the nut-based beverages obtained from the relationship between deformation rate and shear stress at $25,45,80^{\circ} \mathrm{C}$.

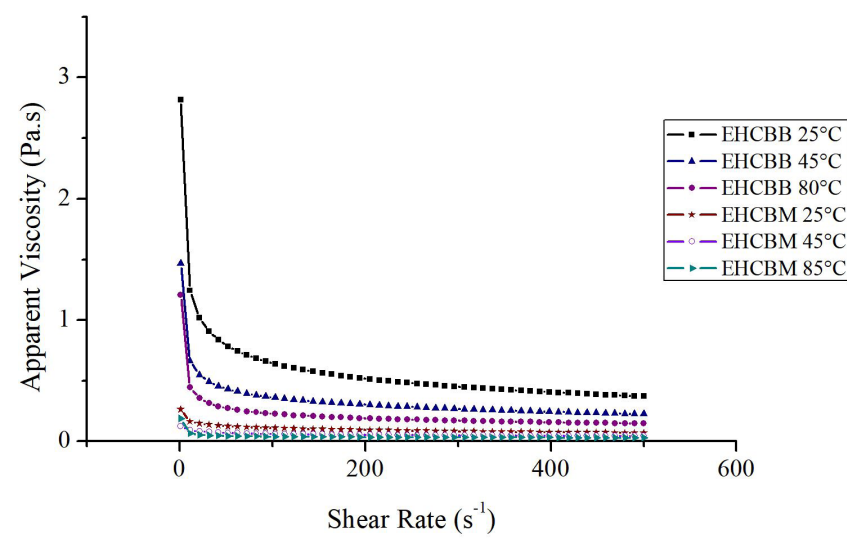

Figure 2. Apparent viscosity of the plant extracts as a function of the deformation rate at $25^{\circ} \mathrm{C}, 45^{\circ} \mathrm{C}$ and $80^{\circ} \mathrm{C}$.

a given fixed shear rate are observed for the nut-based beverage made of Brazil nut and Macadamia, indicating that the apparent viscosity is lower in these extracts.

In Figure 2 is shown the relationship between apparent viscosity $\left(\eta_{\mathrm{ap}}\right)$ and shear rate for the beverages. An increase in the shear rate caused the decrease of the apparent viscosity, which indicates a characteristic behavior of a non-Newtonian pseudoplastic fluid, confirming the results observed in values referring to the flow behavior indices. Lee et al. (2019) observed the same behavior studying Bengal rice milk.

Analyzing the viscosities of the beverages (Figure 2), it was observed a decrease when the temperature increased, that can be explained by the use of the stabilizer carboxymethylcellulose, which according to Selomulyo \& Zhou (2007), solutions with carboxymethylcellulose tend to be highly viscous and stable, but the viscosity decreases during heating. Mathias et al. (2013) verified the rheological behavior of different commercial yoghurts, which, independently of the thickeners used, all yogurt samples analyzed showed a non-Newtonian and pseudoplastic fluid behavior, since there was a decrease in viscosity as a function of the increase in the applied shear rate.

Many authors have observed similar behavior for the rheological study of coconut milk, characterizing it as a pseudoplastic fluid (Tangsuphoom \& Coupland, 2005; Jirapeangtong et al., 2008; Tipvarakarnkoon et al., 2010).
From the industrial point of view, the decrease of the apparent viscosity facilitates the flow of the beverages and the heat exchange during the processing. The nut-based beverage made of Brazil nut and Macadamia presented lower values for the apparent viscosity, in all the studied conditions, requiring less shear rate to flow compared to plant-based beverage made of Brazil nut and Baru, as can be proven by the Bingham model.

It is known that the lower the viscosity of a fluid, the lower the head loss during flow, reducing power costs with pumping and consequently, production costs (Bezerra et al., 2013). The rheological characteristic observed for the beverages demonstrates that the behavior is typical of most food fluids in the food industry. This characteristic can provide the application of the products in the existing equipment and processes, and there is no need to develop new ones, facilitating their large-scale processing in the packaging systems already available in the market.

\section{Conclusion}

The characterization of the rheological behavior showed no differences between the plant-based beverages. The Ostwald-de-Waele model was the best evaluated to describe the beverage behavior, thus, the plant-based beverages were classified as non-Newtonian fluids with pseudoplastic character $(\mathrm{n}<1)$, a characteristic that is ideal to provide the application of the products in existing equipment and processes, facilitating its large scale processing.

The addition of carboxymethylcellulose has contributed to the increase of the product's stability and viscosity, however the viscosity index decreases with the temperature increasing.

The nut-based beverage made of Brazil nut and Macadamia presented the lowest values for shear stress at a given fixed shear rate under all studied conditions, indicating that the apparent viscosity is lower in these extracts, requiring less shear stress for flowing. This fact should be considered in any piping and pump design.

\section{Acknowledgements}

The authors are grateful to FAPEG (Research Foundation of the State of Goiás, Brazil) for the concession of a scholarship to Kamilla Soares Silva and to CAPES (Coordination and Improvement of Higher Level or Education Personnel) for the concession of a scholarship to André Luiz Borges Machado.

\section{References}

Alhendi, A., Yang, W., Goodrich-Schneider, R., Sims, C., Marshall, S., \& Sarnoski, P. J. (2018). Sensory evaluation and flavour analysis of soymilk produced from lipoxygenase-free soya beans after modified processes and pulsed light treatment. International Journal of Food Science \& Technology, 53(6), 1434-1441. http://dx.doi.org/10.1111/ ijfs.13721.

Azeredo, H. M. C. (2012). Fundamentos de estabilidade de alimentos (2. ed). Brasília: EMBRAPA.

Bernat, N., Cháfer, M., Rodríguez-García, J., Chiralt, A., \& GonzálezMartínez, C. (2015). Effect of high pressure homogenisation and heat treatment on physical properties and stability of almond and hazelnut milks. LWT - Food Science and Technology, 62(1), 488-496. 
Bezerra, C. V., Silva, L. H. M., Costa, R. D. S., Mattietto, R. A., \& Rodrigues, A. M. C. (2013). Rheological properties of tropical juices. Brazilian Journal of Food Technology, 16(2), 155-162. http://dx.doi. org/10.1590/S1981-67232013005000020.

Borges, S. F., Pires, V. P., Sampaio, R. M., \& Vélez, H. A. V. (2017). Study of the rheological behavior and stability of cupuaçu pulp (Theobroma grandinflorum). Revista Brasileira de Iniciação Científica, 4(6), 61-75.

Brasil, Ministério da Saúde, Agência Nacional de Vigilância Sanitária. (2005, Setembro 22). Regulamento técnico para produtos protéicos de origem vegetal (Resolução RDC n ${ }^{\circ} 268$, de 22 de setembro de 2005). Diário Oficial [da] República Federativa do Brasil.

Brasil, Ministério da Saúde, Agência Nacional de Vigilância Sanitária. (2013, Março 6). Dispõe sobre a aprovação de uso de aditivos alimentares para produtos de frutas e de vegetais e geleia de mocotó (Resolução RDC n 8 de 06 de março de 2013). Diário Oficial [da] República Federativa do Brasil.

Cantu-Lozano, D., Vigano, J., Lassman, A. A., Cantu, N. A. V., \& Telis-Romero, J. (2013). Sorption isotherms and drying kinetics of grapefruit seeds. Acta Scientiarum Technology, 35(4), 717-723. http://dx.doi.org/10.4025/actascitechnol.v35i4.13658.

Cardarelli, H. R., \& Oliveira, A. J. (2000). Conservação do Leite de Castanha-do-Pará. Scientia Agrícola, 57(4), 617-622. http://dx.doi. org/10.1590/S0103-90162000000400004.

Chhabra, R. P., \& Richardson, J. F. (2008). Non-Newtonian flow and applied rheology: engineering applications (2. ed.). Oxford: Butterworth-Heinemann.

Ferberg, I., Cabral, L. C., Gonçalves, E. B., \& Deliza, R. (2002). Efeito das condições de extração no rendimento e qualidade do leite de Castanha-do-Brasil (Bertholletia excelsa) despeliculada. Boletim CEPPA, 20(1), 75-88.

Gazola, M. B. (2014). Caracterização de polpas e bebidas à base de extrato hidrossolúvel de soja, amora, pitanga e mirtilo - análises reológicas, fitoquímicas, físico-químicas, microbiológicas e sensoriais (Dissertação de mestrado). Universidade Tecnológica Federal do Paraná, Pato Branco.

Jirapeangtong, K., Siriwatanayothin, S., \& Chiewchan, N. (2008). Effects of coconut sugar and stabilizing agents on stability and apparent viscosity of high-fat coconut milk. Journal of Food Engineering, 87(3), 422-427. http://dx.doi.org/10.1016/j.jfoodeng.2008.01.001.

Lee, Y., Dias-Morse, P. N. \& Meullenet J. F. (2019). Effect of rice variety and milling fraction on the starch gelatinization and rheological properties of rice milk. Food Science and Technology, Ahead of Print. http://dx.doi.org/10.1590/fst.17118.

Lopes, M., Duarte, C. M., Nunes, C., Raymundo, A., \& Sousa, I. (2019). Flow Behaviour of Vegetable Beverages to Replace Milk. In F. J. Galindo-Rosales, L. Campo-Deaño, A. M. Afonso, M. A. Alves \& F. T. Pinho. Proceedings of the Iberian Meeting on Rheology (IBEREO 2019) (pp. 83-87). Porto, Portugual: Springer.

Madamba, P. S., Driscoll, R. H., \& Buckle, K. A. (1996). The thin layer drying characteristic of garlic slices. Journal of Food Engineering, 29(1), 75-97. http://dx.doi.org/10.1016/0260-8774(95)00062-3.

Mathias, T. R. S., Andrade, K. C. S., Rosa, C. L. S., \& Silva, B. A. (2013). Rheological evaluation of different commercial yoghurts. Brazilian Journal of Food Technology, 16(1), 12-20. http://dx.doi.org/10.1590/ S1981-67232013005000004.

McLaughlin, C. P., \& Magee, T. R. A. (1998). The determination of sorption isotherm and the isosteric heats of sorption for potatoes. Journal of Food Engineering, 35(3), 267-280. http://dx.doi.org/10.1016/ S0260-8774(98)00025-9.

McMinn, W. A. M. (2006). Thin-layer modeling of the convective, microwave, microwave-convective and microwave-vacuum drying of lactose powder. Journal of Food Engineering, 72(2), 113-123. http:// dx.doi.org/10.1016/j.jfoodeng.2004.11.025.

Mondragón-Bernal, O. L., Alves, J. G. L. F., Teixeira, M. A., Ferreira, M. F. P., \& Maugeri Filho, F. (2017). Stability and functionality of synbiotic soy food during shelf-life. Journal of Functional Foods, 35, 134-145. http://dx.doi.org/10.1016/j.jff.2017.05.021.

Moreira, R. W. M., Madrona, G. S., Branco, I. G., Bergamasco, R., \& Pereira, N. C. (2010). Avaliação sensorial e reológica de uma bebida achocolatada elaborada a partir de extrato hidrossolúvel de soja e soro de queijo. Acta Scientiarum Technology, 32(4), 435-438.

Oliveira, K. H., Souza, J. A. R., \& Monteiro, A. R. (2008). Caracterização reológica de sorvetes. Food Science and Technology, 28(3), 592-598. http://dx.doi.org/10.1590/S0101-20612008000300014.

Patrignani, F., Modesto, M., Michelini, S., Sansosti, M. C., Serrazanetti, D. I., Qvirist, L., Siroli, L., Camprini, L., Mattarelli, P., \& Lanciotti, R. (2017). Technological potential of Bifidobacterium aesculapii strains for fermented soymilk production. Lebensmittel-Wissenschaft + Technologie, 89, 689-696. http://dx.doi.org/10.1016/j.lwt.2017.11.048.

Ribeiro, J. E. S., Sant'ana, A. M. S., Sousa, J. R. T., Queiroga, R. C. R. E., Silva, F. L. H., Santos, C. A. C., El-Aouar, A. A., \& Beltrão Filho, E. M. (2016). Influence of variable water-soluble soy extract and inulin contents on the rheological, technological and sensory properties of grape-flavored yogurt-like beverages made from caprine milk. International Journal of Engineering Research and Applications, 6(4), 21-32. http://dx.doi.org/10.9790/9622-0604042133.

Rodrigues, R. S., Gozzo, A. M., \& Moretti, R. H. (2003). Comportamento reológico de extratos de grãos, farinha integral e isolado protéico de soja. Boletim CEPPA, 21(2), 367-378. http://dx.doi.org/10.5380/cep.v21i2.1171.

Santos, M. G. (2015). Avaliação de estabilidade do extrato hidrossolúvel de castanha-do-brasil (Bertholletia excelsa) (Dissertação de mestrado). Universidade Federal de Goiás, Goiânia.

Sęczyk, L., Świeca, M., \& Gawlik-Dziki, U. (2017). Soymilk enriched with green coffee phenolics - Antioxidant and nutritional properties in the light of phenolics-food matrix interactions. Food Chemistry, 223, 1-7. http://dx.doi.org/10.1016/j.foodchem.2016.12.020. PMid:28069114.

Selomulyo, V. O., \& Zhou, W. (2007). Frozen bread dough: Effects of freezing storage and dough improvers. Journal of Cereal Science, 45(1), 1-17. http://dx.doi.org/10.1016/j.jcs.2006.10.003.

Sethi, S., Tyagi, S. K., \& Anurag, R. K. (2016). Plant-based milk alternatives an emerging segment of beverages: a review. Journal of Food Science and Technology, 53(9), 3408-3423. http://dx.doi. org/10.1007/s13197-016-2328-3. PMid:27777447.

Silva, L. T. S. (2014). Propriedades termofísicas e comportamento reológico do leite e do soro de búfala (Dissertação de mestrado). Universidade Estadual do Sudoeste da Bahia, Itapetinga.

Sousa, E. P., Queiroz, A. J. M., Figueirêdo, R. M. F., \& Lemos, D. M. (2014). Rheological behavior and effect of temperature of pequi pulp at different concentrations. Brazilian Journal of Food Technology, 17(3), 226-235. http://dx.doi.org/10.1590/1981-6723.1214.

Sousa, S. F., Queiroz, A. J. M., Figueirêdo, R. M. F., \& Silva, F. B. (2017). Rheological behavior of whole and concentrated noni pulp. Brazilian Journal of Food Technology, 20, 1-10.

Steffe, J. F. (1996). Rheological methods in food process engineering. Michigan: Freeman Press.

Tangsuphoom, N., \& Coupland, J. (2005). Effect of heating and homogenization on the stability of coconut milk emulsions. Journal of Food Science, Raleigh, 70(8), 499-470. http://dx.doi. org/10.1111/j.1365-2621.2005.tb11516.x.

Tipvarakarnkoon, T., Einhorn-Stoll, U., \& Senge, B. (2010). Effect of modified Acacia gum (SUPER GUMTM) on the stabilization of coconut o/w emulsions. Food Hydrocolloids, 24(6-7), 595-601. http://dx.doi.org/10.1016/j.foodhyd.2010.03.002. 
Zheng, J., Wu, J., Dai, Y., Kan, J., \& Zhang, F. (2017). Influence of bamboo shoot dietary fiber on the rheological and textural properties of milk pudding. Lebensmittel-Wissenschaft + Technologie, 84, 364-369. http://dx.doi.org/10.1016/j.lwt.2017.05.051.
Wang, Y., Xing, J., Wang, R., \& Guo, S. (2017). The analysis of the causes of protein precipitate formation in the blanched soymilk. Food Chemistry, 218, 341-347. http://dx.doi.org/10.1016/j. foodchem.2016.09.084. PMid:27719919. 